\title{
Introduction to the Engaging Governance Minitrack
}

\author{
Lobna Hassan \\ Tampere University \\ Hanken School of \\ Economics \\ lobna.hassan@tuni.fi
}

\author{
Mattia Thibault \\ Tampere University \\ mattia.thibault@tuni.fi
}

\author{
J. Tuomas Harviainen \\ Tampere University \\ tuomas.harviainen@tun \\ i.fi
}

\author{
Juho Hamari \\ Tampere University \\ juho.hamari@tuni.fi
}

Despite the continuous increase of global population and the growing complexity and fragmentation of societies, technology continues to offer novel tools that facilitate citizen participation in governance activities. In the last few years, we have seen an increased utilisation of games, game-based approaches [1,5], and emerging social media [3] in various domains of public participation. Concepts such as playable cities [2,6], urban gamification [7], and civic games [10] highlight the large-scale potential that emerging technologies and approaches hold for the cities of the future, going as far as to imagine future cities that utilise a combination of virtual reality and game dynamics to facilitate their core governance practices and citizen participation [4].

Accordingly, we could argue that strategies for facilitating engagement in governance are available and often utilized. Nonetheless, public engagement often swings between the extremes of being nonexistent or being disruptive and unsustainable, as in the Arab Spring [8], Occupy Wall Street [9], and many city alteration movements [7]. Both the lack of citizen engagement and unsustainable engagement are to the detriment of governance and democratic practices.

In its second year, The Engaging Governance minitrack attracted a wide range of submissions across empirical and conceptual research, out of which, three were accepted for HICSS55:

Fox in the Henhouse: The Delegation of Regulatory and Privacy Enforcement to Big Tech by William Bendix, and Jon MacKay discusses the delicate relationship between Big Tech companies and law enforcement agencies, reflecting on consumer and societal protection in our increasingly digitised world.

Governance Challenges in Open Government Data Ecosystems: A Case Study from the Financial Sector in Norway by Christian Schultz, and Alexander Kempton presents a case study of the public data ecosystem in Norway, reflecting on differing stakeholders and interests in data.

Understanding Drivers and Challenges of Multi-actor Collaborations at the Local Level by
Qianli Yuan, Karyn Doke, Mila Gasco-Hernandez, J. Ramon Gil-Garcia, Mariya Zheleva, and Petko Bogdanov delves deeper into local government and stakeholders in governance.

\section{References}

[1] J. L. Geurts, Duke, R. D., \& Vermeulen, P. A., "Policy gaming for strategy and change". Long Range Planning, 40(6), 2007, pp. 535-558.

[2] A. Nijholt, "Playable Cities", 2017 Springer, Singapore.

[3] R. Effing, Van Hillegersberg, J., \& Huibers, T, "Social media and political participation: are Facebook, Twitter and YouTube democratizing our political systems?", Proceedings of the International conference on electronic participation, 2011, pp. 2535. Springer, Berlin, Heidelberg.

[4] M. Thibault, O. Buruk, L. Hassan, \& J. Hamari, "Anagenesis: A framework for gameful, playful and democratic future smart cities.”. In Organizational Gamification: Theories and Practices of Ludified Work in Late Modernity (p. 201). Routledge, 2021.

[5] L. Hassan, \& Hamari, J. "Gameful civic engagement: A review of the literature on gamification of e-participation". Government Information Quarterly, 37(3), 2020.

[6] L. Hassan, \& Thibault M, "Critical Playable Cities". In: Nijholt A. (eds) Making Smart Cities More Playable. Gaming Media and Social Effects, 2020 Springer, Singapore.

[7] M. Thibault, "Towards a Typology of Urban Gamification" Proceedings of the 52nd Annual Hawaii International Conference on System Sciences (HICSS), 2019., pp. 1476-1485.

[8] H. Abdelghaffar, \& Hassan, L, "The Use of Social Networks in Achieving e-Democracy in the Arab Spring Countries", International journal of EAdoption (IJEA), 8(2), 2016, pp. 17-33.

[9] C. Calhoun, "Occupy wall street in perspective", British journal of sociology, 64(1), 2013, pp. 26-38.

[10] K. Schrier, "We the Gamers: How Games Teach Ethics and Civics”, Oxford University Press, 2021. 